\title{
LIPOLYTIC CAPACITY OF Pseudomonas spp. ISOLATED FROM REFRIGERATED RAW MILK
}

\author{
CAPACIDADE LIPOLÍTICA DE Pseudomonas spp. ISOLADAS DE LEITE CRU \\ REFRIGERADO
}

\author{
Kelly Molin de ALMEIDA ${ }^{1}$; Samera Rafaela BRUZAROSKI²; Daniel ZANOL ${ }^{2}$; \\ Joice Sifuentes dos SANTOS $^{3}$; Elsa Helena Walter de SANTANA ${ }^{3 *}$ \\ 1. Graduate student, Universidade Norte do Paraná; 2. Undergraduate student, Universidade Norte do Paraná; 3. \\ Professor, PhD, Universidade Norte do Paraná, elsahws@ hotmail.com
}

\begin{abstract}
The psychrotrophic bacteria growth in refrigerated milk is responsible for the production of heat resistant enzymes, including those which have lipolytic capacity. Lipases can cause rancidity and off-flavor in pasteurized and UHT milk, milk powder and cheese. Pseudomonas spp. is the major genera responsible by lipases synthesis, mainly Pseudomonas fluorescens. The lipolytic capacity of Pseudomonas spp. (1182 strains) and P. fluorescens (158 strains) isolated from cooling tank and bulk milk transportation were tested. Pseudomonas spp. strains were isolated by Pseudomonas Agar Base, adding the supplement cephalotin, fusidic acid, cetrimide- CFC ( $\left.30^{\circ} \mathrm{C} / 48 \mathrm{~h}\right)$ and Pseudomonas Cetrimide Agar with $10 \%$ of glicerol $\left(21^{\circ} \mathrm{C} / 48 \mathrm{~h}\right)$ to determine P. fluorescens. The strains lipolytic capacity were tested with Tributyrin Agar $\left(21^{\circ} \mathrm{C} / 72 \mathrm{~h}\right)$. Lipolytic indexes of Pseudomonas spp. were $51.4 \%$ and $67.2 \%$ in cooling tank and bulk milk transportation ( $\mathrm{p}<0.05)$, respectively. P. fluorescens lipolytic capacity indexes were $26.4 \%$ from strains isolated from cooling tank and $41 \%(\mathrm{p}<0.05)$ from strains isolated from bulk milk transportation. High lipolytic indexes had been found in the strains isolated from refrigerated raw milk sent to manufacturing. Refrigeration temperature and storage time may contribute to the difference observed between two points of collection evaluated in this study.
\end{abstract}

KEYWORDS: Psychrotrophic. Enzymes. Quality.

\section{INTRODUCTION}

High counts of psychrotrophic bacteria in raw milk are directly related to poor hygienic conditions during production and milking, and to the time and temperature of milk storage (ARCURI et al., 2008). Low psychrotrophic bacteria counts are essential to maintain milk quality, once the metabolic activity of these microorganisms modify milk biochemical constituents (ARCURI et al., 2008), such as lipid, protein and carbohydrate degradation (COUSIN, 1982), limiting the shelf life of fluid milk and its products (SANTOS et al. 2009; ARCURI et al., 2008).

Lipolysis involves the enzymatic hydrolysis of milk lipids, producing free fatty acids and glycerol. Lipases can be of endogen origin, being the lipoprotein lipase the most important, or exogenous, produced by microbial activity. Bacterial lipases are not inactivated by heating, and cause rancidity and off-flavor in pasteurized and UHT milk, milk powder and cheese (JONGHE et al., 2011; COUSIN, 1982). Pseudomonas spp. is the major genera responsible by lipases synthesis, mainly Pseudomonas fluorescens (MU et al., 2008; DEETH; FITZ-GERALD, 2006; SHAH, 1994).

Thus, this study aimed to evaluate the lipolytic capacity of Pseudomonas spp. strains and
P. fluorescens isolated from refrigerated raw milk from cooling tanks of rural properties and from bulk milk transportation responsible for the raw milk transportation to the dairy industry.

\section{MATERIAL AND METHODS}

Raw milk samples were collected between June 2013 and February 2014. A total of 37 samples were collected from cooling tanks (CT) from eight rural properties from Paraná State, Brazil, 48 h after the milking. Samples from bulk milk transportation (BMT) of the same rural properties were also collected, in a total of nine samples. The milk temperature indicated in equipment was recorded.

Pseudomonas spp. strains were isolated by Pseudomonas Agar Base, adding the supplement cephalotin, fusidic acid, cetrimide (CFC) (Himedia, Mumbai, Índia), at $30^{\circ} \mathrm{C} / 48 \mathrm{~h}$ (FAGUNDES et al., 2006). To determine $P$. fluorescens, Pseudomonas Cetrimide Agar (Himedia, Mumbai, India) was incubated at $21^{\circ} \mathrm{C} / 48 \mathrm{~h}$ (SANTOS et al., 2009; KING, 1954). To verify the Pseudomonas spp. and $P$. fluorescens strains isolated from milk samples lipolytic capacity, plates with maximum of 100 colony formatting units were selected, and considered positive the colonies with transparent halo. Thus, 1182 Pseudomonas spp. strains and 158 
P. fluorescens strains were tested. Positive colonies were plated on Tributyrin Agar (Himedia, Mumbai, India) and incubated at $21^{\circ} \mathrm{C} / 72 \mathrm{~h}$ (FRANK et al, 1992).

Differences in lipolytic capacity of strains isolated from CT and BMT were tested by Chisquare test $(\mathrm{p}<0.05)$. The null hypothesis tested was that the lipolityc strains isolated from CT frequency was not different from that of BMT. Thus, the alternative hypothesis tested was that the lipolityc strains isolated from CT frequency was the same from that of BMT.

\section{RESULTS AND DISCUSSION}

From Pseudomonas spp. strains isolated from CT milk, 51.4\% presented lipolytic capacity. Among Pseudomonas spp. strains isolated from BMT, a higher number of $67.2 \%$ presented lipolytic capacity (Table 1). Lipases are mainly produced at $21{ }^{\circ} \mathrm{C}$, but they also occur at refrigeration temperature, during the log phase final of cellular growing (MAHIEU, 1991). This fact can explain the difference $(p<0.05)$ observed in this study in the lipolytic strains frequency from CT and BMT (Table 1). The result of Chi-square test is to reject the null hypothesis, that is, the lipolityc strains frequency isolated from CT was different from that of BMT. At low temperature, Pseudomonas spp. had a short lag phase and a long stationary phase, and can survive for extended periods in milk residues (SORHAUNG; STEPANIAK 1997). Kumaresan et al. (2007) observed during 14 days a difference in lipolytic activity at $4{ }^{\circ} \mathrm{C}$ and $7{ }^{\circ} \mathrm{C}$, with lower lipolytic capacity in temperatures under $4{ }^{\circ} \mathrm{C}$. According to these authors, the enzymatic activity also depends on the raw milk refrigeration time, tested at $0,3,5,7$ and 14 days of storage. In the present study, a similar result was obtained. Difference $(\mathrm{p}<0.05)$ between the number of lipolytic strains in milk storaged during $48 \mathrm{~h}$ (CT), with mean temperature of $3.8^{\circ} \mathrm{C}$, and the raw milk delivered to the dairy industry (BMT), with mean temperature of $6.6^{\circ} \mathrm{C}$ was observed (Table 1$)$.

Table 1. Lipolytic capacity of Pseudomonas spp. and P. fluorescens strains isolated from raw refrigerated milk from cooling tanks (CT) of rural properties and from bulk milk transportation (BMT) responsible for the raw milk transportation to the dairy industry.

\begin{tabular}{lccccccc}
\hline \multirow{2}{*}{ Sample } & \multirow{2}{*}{$\mathrm{T}^{\mathrm{o}} \mathrm{C}$} & \multicolumn{3}{c}{ Pseudomonas spp strains } & \multicolumn{3}{c}{ P. fluorescens strains } \\
\cline { 3 - 8 } & & TS & LS & LS (\%) & TS & LS & LS (\%) \\
\hline CT & 3.8 & 1002 & 515 & $51.4^{\mathrm{b}}$ & 129 & 34 & $26.4^{\mathrm{b}}$ \\
BMT & 6.6 & 180 & 121 & $67.2^{\mathrm{a}}$ & 29 & 12 & $41.0^{\mathrm{a}}$ \\
Total & --- & 1182 & 636 & 53.8 & 158 & 46 & 29.1 \\
\hline
\end{tabular}

Values with different lower cases in the same column differ significantly by the Chi-Square test $(\mathrm{p}<0.05)$; CT $=$ raw refrigerated milk from cooling tanks; BMT $=$ raw refrigerated milk from bulk milk transportation. $\mathrm{TS}=$ Tested strains; LS= Lipolytic strains.

The use of refrigeration without good practices during the raw production allows the psychrotrophic microorganisms growing that produces heat resistant lipases (IZIDORO et al., 2013). At low temperatures $\left(4{ }^{\circ} \mathrm{C}\right)$, the active transportation and the inner nutrients diffusion to bacterial cells are reduced. To compensate this mechanism, enzymatic production is increased, including lipases production (BUCK et al., 1986).

When the $P$. fluorescens strains lipolytic capacity in the raw refrigerated milk from cooling tanks $\left(3.8^{\circ} \mathrm{C}\right)$ was compared to that from bulk milk transportation $\left(6.6^{\circ} \mathrm{C}\right)$, we observed indexes of $26.4 \%$ and $41 \%$, respectively (Table 1). Different results were observed by Arcuri et al. (2008), where all $P$. fluorescens strains isolated at $4{ }^{\circ} \mathrm{C}, 7^{\circ} \mathrm{C}, 10$ ${ }^{\circ} \mathrm{C}$ and $21^{\circ} \mathrm{C}$ had lipolytic capacity. The enzymatic production of lipases, proteases and phospholipases is related with the temperature, microorganism growing phase, oxygen availability and medium composition. Its activity depends on temperature, $\mathrm{pH}$ and substrate concentration (NUÑEZ; NUÑEZ, 1983).

Milk thermal treatment such as pasteurization and ultra high temperature (UHT) reduces the lipolytic activity in $75 \%$ and $91.6 \%$, respectively. However, extracellular lipases produced by psychrotrophic bacteria resist to sterilization at $130{ }^{\circ} \mathrm{C} / 15$ seconds (SHAH, 1994). The majority of bacterial lipases had specificity to sn-1 and sn-3 positions of the triacylglycerol, and can hydrolyse monoacylglicerols and diacylglycerols at higher speed when compared to triacylglicerols (ARCURI et al., 2006).

Besides rancidity and bitter taste, other problems and defects are caused due the Pseudomonas spp.enzymatic activity such as UHT milk gelation, fruit flavor (JONGHE et al., 2011; 
MU et al., 2009), thermal stability, ethanol stability, false positive result to the search of milk fraud by wheat addition through the sialic acid determination and reduction in the cheese yielding (ARCURI et al., 2008).

\section{CONCLUSION}

In the refrigerated raw milk studied, high lipolytic capacity indexes of Pseudomonas spp. and $P$. fluorescens strains were observed, with higher values in milk from bulk milk transportation delivered to the dairy industry. Refrigeration temperature and storage time may contribute to the difference observed in the two collection points.

RESUMO: A multiplicação de bactérias psicrotróficas em leite refrigerado pode promover a síntese de enzimas resistentes ao calor, entre elas aquelas que tem capacidade lipolítica. As lipases podem promover rancidez, e defeitos de sabor em leite pasteurizado, UHT, leite em pós e queijos. Pseudomonas spp. é o principal gênero responsável pela síntese desta enzimas, principalmente a espécie Pseudomonas fluorescens. Avaliou-se a capacidade lipolítica de 1182 cepas de Pseudomonas spp. e 158 cepas de $P$. fluorescens isoladas de amostras de leite de tanques de resfriamento (TR) e caminhão tanque (CT) enviado ao beneficiamento. Foi utilizado o Agar base Pseudomonas com suplemento cephalotin, fusidic acid, cetrimide - CFC $\left(30^{\circ} \mathrm{C} / 48 \mathrm{~h}\right)$ para isolamento das pseudomonas e Pseudomonas Cetrimide Agar com $10 \%$ de glicerol $\left(21^{\circ} \mathrm{C} / 48 \mathrm{~h}\right)$ para a espécie $P$. fluorescens. Para avaliação da capacidade lipolítica as cepas fora semeadas em Ágar Tributirina $\left(21^{\circ} \mathrm{C} / 72 \mathrm{~h}\right)$. O índice de lipólise das cepas de Pseudomonas spp. provenientes do leite do tanque de resfriamento e do caminhão tanque $(\mathrm{p}<0,05)$ foram de $51,4 \%$ e $62,7 \%$, respectivamente. Foram também observados índices de capacidade lipolítica de $P$. fluorescens de 26,4\% e 41\% (p<0,05) para TR e CT, respectivamente. Altos índices de cepas lipolíticas foram encontrados nas cepas isoladas do leite cru refrigerado enviado ao beneficiamento. Temperatura de refrigeração e tempo de estocagem podem ter contribuído para a diferença observada na população lipolítica dos dois pontos de coleta avaliados.

PALAVRAS-CHAVE: Psicrotróficos. Enzimas. Qualidade.

\section{REFERENCES}

ARCURI, E. F. et al. Microbiological quality of refrigerated milk on farms. Brazilian Journal of Veterinary and Animal Science, Belo Horizonte, v. 58, n. 3, p. 440-446, 2006. http://dx.doi.org/10.1590/S010209352006000300024.

ARCURI, E. F. et al. Counting, isolation and characterization of psychrotrophic bacteria from refrigerated raw milk. Ciência Rural, Santa Maria, v. 38, n. 8, p. 2250-2255, 2008. http://dx.doi.org/10.1590/S010384782008000800025 .

BUCK, A. R.; HAYES, P. R.; ROBINSON, D. S. Lipase production by a strain of Pseudomonas fluorescens in whole milk and skimmed milk. Food Microbiology, Ilinois , v. 3, n. 1, p. 37-44, 1986.

http://dx.doi.org/10.1016/S0740-0020(86)80024-7.

COUSIN, M.A. Presence and activity of psychrotrophic microorganisms in milk and dairy products: a review. Journal of Food Protection, Des Moines, v. 45, n. 2, p. 172-207, 1982.

DEETH, H. C.; FITZ-GERALD, C.H. Lipolytic enzymes and hydrolytic rancidity. In: FOX, P. F.; MCSWEENEY, P. L. H. (Ed.). Advanced dairy chemistry: lipids. 3. rd. New York: Springer, 2006. p. 481556.

FAGUNDES, C. M. et al. Presence of Pseudomonas spp. in milking phases with different hygienic handling procedures and in refrigerated milk. Ciência Rural, Santa Maria, v. 36, n. 2, p. 568-572, 2006. http://dx.doi.org/10.1590/S0103-84782006000200032. 
FRANK, J. F.; CHRISTEN, G. L.; BULLERMAN, L. B. Tests for groups of microorganisms. In:

MARSHALL, R. T. (Ed.). Standard methods for the examination of dairy products. 16. ed. New York: American Public Health Association, 1992. p. 837-856.

IZIDORO, T. B. et al. Effect of psychrotrophic growth on the milk fat fraction at different temperatures of storage. Journal of Food Science, v. 78, n. 4, p. 615-618, 2013. http://dx.doi.org/10.1111/1750-3841.12091.

JONGUE, V. et al. Influence of storage conditions on the growth of Pseudomonas species in refrigerated raw milk. Applied and Environmental Microbiology, Washington, v. 77, n. 2, p. 460-470, 2011. http://dx.doi.org/10.1128/AEM.00521-10.

KING, E. O. Two simple media for the demonstration of pyocyanin and fluorescein. Journal of Laboratory and Clinical Medicine, v.44, n.2, p.301-307, 1954. http://www.ncbi.nlm.nih.gov/pubmed/13184240.

KUMARESAN, G. et al. Psychrotrophic spoilage of raw milk at different temperatures of storage. Journal of Applied Sciences Research, Jordan, v. 3, n. 11, p. 1383-1387, 2007.

MAHIEU, H. Modificaciones de la leche después de su recogida. In: LUQUET, F. M. Leche y productos lácteos: la leche de la mama a la lechería. Zaragoza: Acribia, 1991. p. 181-226.

MU, Z. et al. Purification and properties of a heat-stable enzyme of Pseudomonas fluorescens Rm12 from raw milk. European Food Research and Technology,New York, v. 228, n. 5, p. 725-734, 2009.

http://dx.doi.org/10.1007/s00217-008-0983-y.

NUÑEZ, M.; NUÑEZ, J. A. Proteasas de psicrotrofos gram negativos. Efectos sobre la leche y los productos lácteos. Revista Espanhola de Lecheria, Madri, v.130, p.251-260, 1983.

SANTOS, P. A.; SILVA, M. A. P.; SOUZA, C. M.; ISEPON, J. S.; OLIVEIRA, A. N.; NICOLAU, E. S Effect of time and temperature of refrigeration in the development of psychrotrophic microrganisms in cooled raw milk collected in the macroregion of Goiânia, GO. Ciência Animal Brasileira, Goiânia, v. 10, n. 4, p. 1237$1245,2009$.

SHAH, N. P. Psychrotrophic in Milk: a Review. Milchwissenschaft, Kempten, v. 49, n. 8, p. 432-437, 1994.

SORHAUNG, T.; STEPANIAK, L. Psychrotrophics and their enzymes in milk and dairy products: Quality aspects. Trends in Food Science \& Technology, v.8, n. 2, p. 35-41, 1997.

http://dx.doi.org/doi:10.1016/S0924-2244(97)01006-6. 